Article

\title{
New HVAC Sustainability Index-TWI (Total Water Impact)
}

\author{
Alexandre F. Santos $1,2,3, * \mathbb{C}$, Pedro D. Gaspar $1,3, * \mathbb{C}$ and Heraldo J. L. de Souza $2, *$ \\ 1 Department of Electromechanical Engineering, University of Beira Interior, 6201-001 Covilhã, Portugal \\ 2 FAPRO-Faculdade Profissional, 80230-040 Curitiba, Brazil \\ 3 C-MAST-Centre for Mechanical and Aerospace Science and Technologies, 6201-001 Covilhã, Portugal \\ * Correspondence: projetos.etp@gmail.com (A.F.S.); dinis@ubi.pt (P.D.G.); \\ heraldosouza1@gmail.com (H.J.L.d.S.); Tel.: +55-413-332-7025 (A.F.S.); +351-275-329-759 (ext. 3759) (P.D.G.); \\ +55-419-997-48928 (H.J.L.d.S.)
}

Received: 24 January 2020; Accepted: 27 March 2020; Published: 1 April 2020

check for updates

\begin{abstract}
Sales of air conditioning are growing rapidly in buildings, more than tripling between 1990 and 2016. This energy use for air conditioning comes from a combination of rising temperatures, rising population and economic growth. Energy demand for climate control will triple by 2050, consuming more energy than that currently consumed altogether by the United States, the European Union and Japan. This increase in energy will directly impact water consumption, either to directly cool a condenser of an equipment or to serve indirectly as a basis for energy sources such as hydroelectric power that feed these heating, ventilation and air conditioning (HVAC) systems. Knowing the unique and growing importance of water, a new index, Total Water Impact (TWI) is presented, which allows a holistic comparison of the impact of water use on water, air and evaporative condensation climate systems. 200 and 500 TON (tons of refrigeration) air-cooled and water-cooled systems are theoretically compared to evaluate the general water consumption level. The TWI index is higher in the smallest water condensing system. That is, holistically, water consumption is higher in the water condensing system than in the air condensing system. Thus, this index provides a new insight about energy consumption and ultimately, about sustainability.
\end{abstract}

Keywords: HVAC; water-cooled condenser; air-cooled condenser; evaporative; TWI

\section{Introduction}

According to the Worldwide Fund for Nature (WWF) [1], there are more than 326 quintillion liters of water on earth. Less than $3 \%$ of all this water is freshwater, and of this amount, more than two thirds are in polar ice caps and icebergs. Also, according to the Brazilian Ministry of Environment [2], freshwater is not evenly distributed across the globe. Its distribution depends essentially on the ecosystems that make up the territory of each country. According to the International Hydrological Program of the United Nations Educational, Scientific and Cultural Organization (UNESCO), in South America, there is $26 \%$ of the total available freshwater on the planet and only $6 \%$ of the world population. Asia has $36 \%$ of total water and is home to $60 \%$ of the world's population (see Figure 1) [3].

Daily water consumption varies widely around the globe. In addition to site availability, average water consumption is strongly related to the country's development and economic levels. Each person needs, on a daily basis, at least 40 liters of water to drink, shower, brush their teeth, wash their hands and cook. However, UN data [4] indicate that a European, who has $8 \%$ of the world's freshwater on its territory, consumes an average of 150 liters of water per day. An Indian only consumes 25 liters a day. According to UNESCO estimates to 2025, based on the current rate of population growth and the 
failure to establish sustainable water consumption, this will lead to a human consumption up to $90 \%$, leaving only $10 \%$ for other living beings on the planet [3].

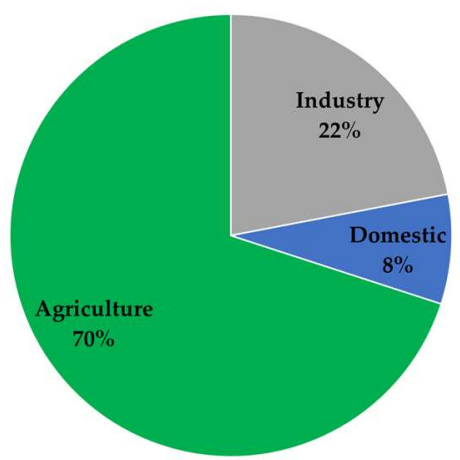

(a)

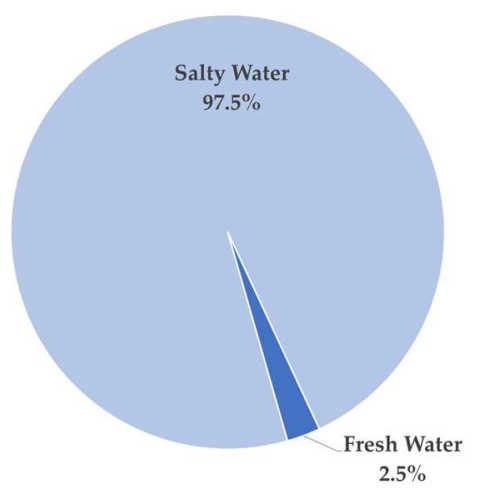

(b)

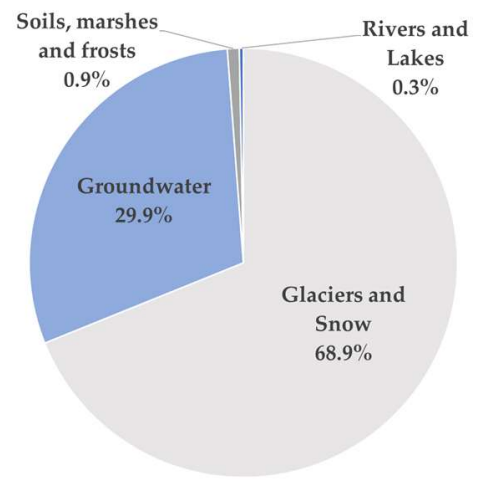

(c)

Figure 1. World water consumption and water distribution [3]. (a) Water consumption, (b) global total water, (c) $2.5 \%$ global total freshwater.

Brazil, with an area of approximately 8,514,876 km² [5] and more than 190 million inhabitants, is today the fifth country in the world both in territorial extension and population. Due to its continental dimensions, Brazil has great contrasts related not only to climate, original vegetation and topography, but also to population distribution and economic and social development, among other factors.

Overall, Brazil is a privileged country in terms of volume of water resources, as it houses $13.7 \%$ of the world's freshwater. However, the freshwater availability is not uniform. As shown in Figure 2, over $73 \%$ of the country's available freshwater is in the Amazon basin, which is inhabited by less than $5 \%$ of the population.

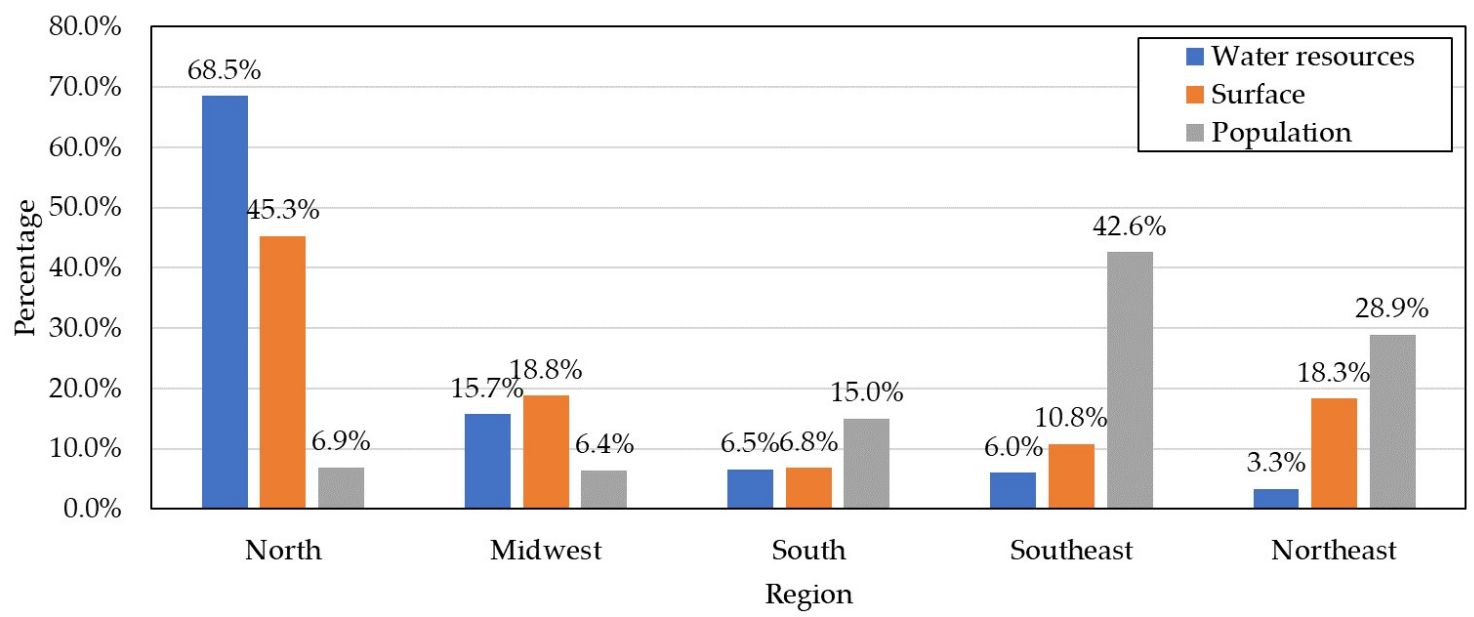

Figure 2. Distribution of water resources in the regions of Brazil [6].

Only $27 \%$ of Brazil's water resources are available to other regions, where $95 \%$ of the country's population lives. Not only is water availability non-uniform, but the supply of treated water reflects the contrasts in the development of Brazilian states. While in the Southeast region, $87.5 \%$ of households are served by a water distribution network, in the Northeast the percentage is only $58.7 \%$.

Brazil also has high water waste: from $20 \%$ to $60 \%$ of treated drinking water is lost in distribution, depending on the conservation conditions of the supply networks. In addition to these water losses on the way between the treatment plants and the consumer, waste is also high at home, for example, involving the time required to take a bath, how the bath is taken, the large volume of the toilet water 
deposit, washing dishes with running water, the use of the hose as a broom to clean sidewalks, how cars are washed, etc. [6].

According to the International Energy Agency (IEA), there are over 500 million air conditioners in the world. Additionally, there are 2.8 billion people living in the hottest places in the world and only $8 \%$ have air conditioning. The numbers of air conditioners will increase from 1.6 billion in 2018 to 5.6 billion by 2050. Thus, 10 new air conditioners will be sold every second. The power supply for air conditioning by 2050 will be equivalent to the current USA, European Union and Japan electrical demand. Due to the importance of energy efficiency and water use in heating, ventilation and air conditioning (HVAC) systems, the aim of this paper is to generate a balance of these two resources [7].

HVAC systems are among the major consumers of freshwater. According to the Brasilian Association of Refrigeration, Air Conditioning, Ventilation and Heating (ABRAVA-Associação Brasileira de Refrigeração, Ar Condicionado, Ventilação e Aquecimento), the power capacity installed in Brazil will reach 60 million tons of refrigeration by 2029 [8]. Knowing the importance and connection of HVAC systems and water consumption, the aim of this work is to create an index to measure direct and indirect water consumption in HVAC systems.

\section{Power Generation and Water Consumption in Brazil, Portugal and the USA}

Water is present in over $70 \%$ of the biosphere. It is an essential resource for power plants. A survey was conducted in the United States of America (USA) by the National Renewable Energy Laboratory (NRL) on water consumption, extracting factors for electricity generating technologies. This data was not found for other countries. The USA energy matrix and the water consumption per kWh generated by different power sources is shown in Figure 3 [9].

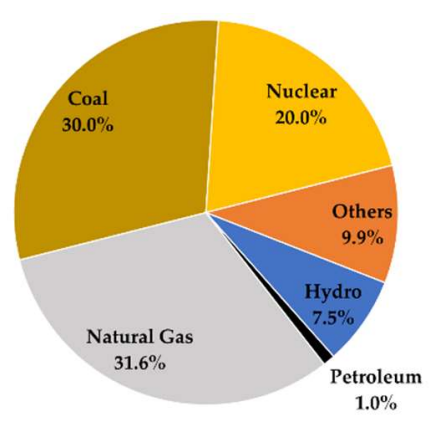

(a)

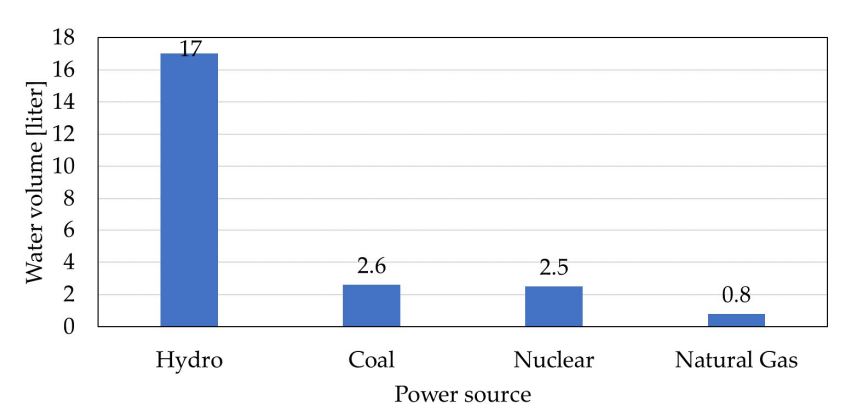

(b)

Figure 3. USA energy matrix and water consumed to generate $1 \mathrm{kWh}$ of electricity. (a) USA energy matrix (ASHRAE-American Society of Heating, Refrigerating and Air-Conditioning Engineers), (b) water consumed to generate $1 \mathrm{kWh}$ of electricity [9].

According to Portuguese Renewable Energy Association (APREN-Associação Portuguesa de Energias Renováveis), renewable energy systems generated 17.2 GWh during the first half of 2018, which represents $61 \%$ of the mainland Portugal's electricity production $(28.2 \mathrm{GWh})$. This result is largely driven by the increased availability of resources, especially water and wind [10]. In that six month period, it is also worth highlighting a set of 623 non-consecutive hours (equivalent to 26 days) in which renewable electricity alone was enough to supply Portuguese electricity consumption (Figure 4).

In Brazil, according to the national energy balance of 2018 [11], the distribution of electric power generation has the distribution shown in Figure 5. Hydroelectric power generation is predominant, with a share of $65.2 \%$. In Brazil, there is a tax incentive for the construction of small hydroelectric plants, thus the total share of small hydroelectric and hydroelectric plants is very large. The share of solar and wind plants in electricity production in Brazil is still small. 


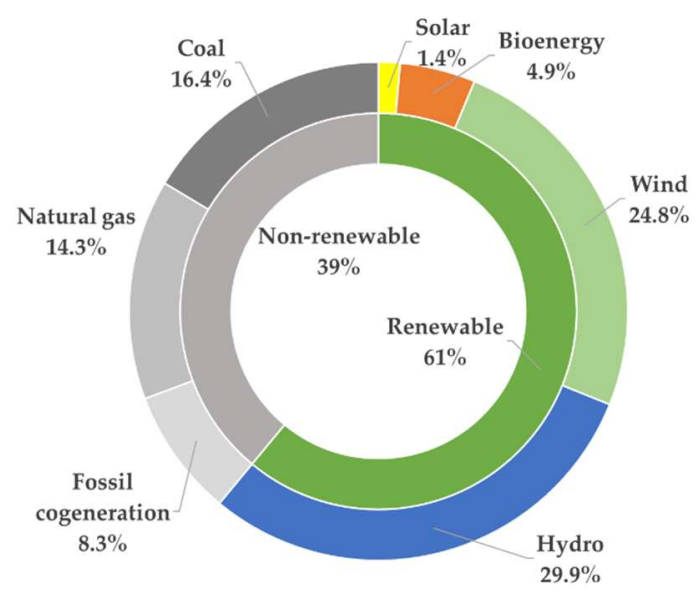

Figure 4. Portugal's electric energy matrix [10].

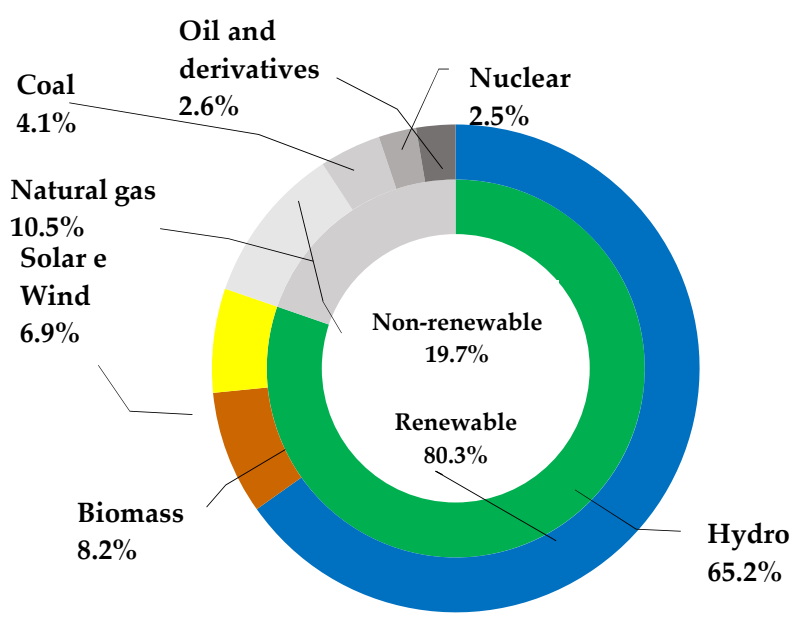

Figure 5. Brazil's electric energy matrix [11].

Figure 6 shows that the hydroelectric is the highest in Brazil, USA and Portugal, respectively. Although coal, biomass and oil have different amounts of pollution rates for power generation through thermoelectricity, the principle of heat transformation for energy and the need of water for steam generation are similar, thus they are considered together.

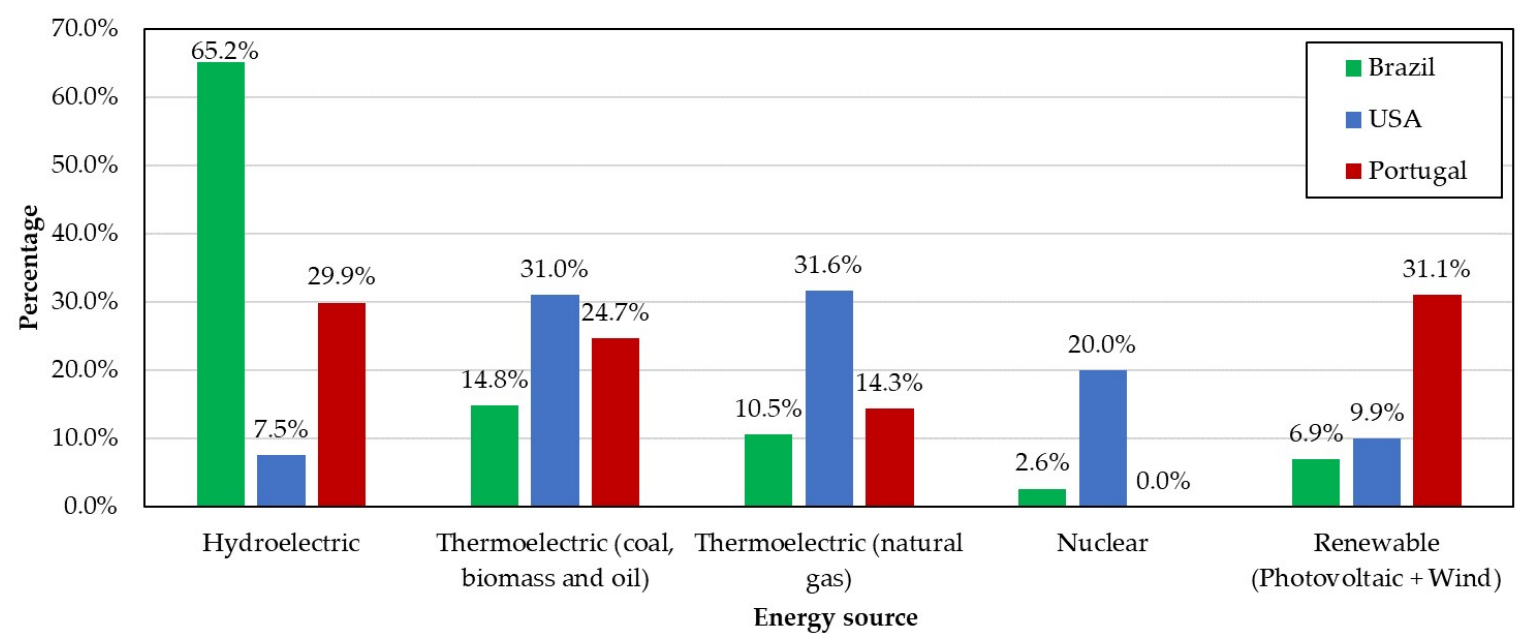

Figure 6. Electricity Generation types in Brazil, USA and Portugal. 
Due to the lack of studies on the amount of water used per kWh generated in energy sources such as photovoltaic and wind, even knowing that water is needed to clean the photovoltaic panels and wind turbine propellers, a null water demand will be considered. Equation (1) provides the number of liters of water per kWh generated in the country required for each of these sources.

$$
\operatorname{LAG}(\text { country })=(\% \text { ghca })+(\% \text { gtca })+(\% \text { gtgnca })+(\% \text { gnca })+(\% \text { goca })
$$

where LAG(country) is liters of water per kWh generated in the country, \%ghca is \% hydroelectric generation-water consumption per kWh hydroelectric, \%gtca is \% coal and oil thermoelectric generation-water consumption per thermoelectric $\mathrm{kWh}$ \% gtgnca is $\%$ thermoelectric generation natural gas-water consumption per thermoelectric $\mathrm{kWh}$ \% gnca is \% nuclear generation-water consumption per nuclear $\mathrm{kWh}$ and \%goca is \% generation from other sources (renewable)-water consumption per $\mathrm{kWh}$ others.

$$
\begin{aligned}
& \text { LAG }(\text { Brazil })=(0.652 \times 16.2)+(0.148 \times 2.49)+(0.105 \times 0.72)+(0.206 \times 2.412)+(0.069 \times 0) \\
& \text { LAG }(\text { Brazil })=11.071 \mathrm{~L} / \mathrm{kWh} \\
& \mathrm{LAG}(\text { USA })=(0.075 \times 16.200)+(0.3001 \times 2.490)+(0.316 \times 0.720)+(0.200 \times 2.412)+(0.99 \times 0) \\
& \mathrm{LAG}(\text { USA })=2.697 \mathrm{~L} / \mathrm{kWh} \\
& \mathrm{LAG}(\text { Portugal })=(0.299 \times 16.2)+(0.247 \times 2.49)+(0.143 \times 0.72)+(0 \times 2.412)+(0.311 \times 0) \\
& \mathrm{LAG}(\text { Portugal })=5.561 \mathrm{~L} / \mathrm{kWh}
\end{aligned}
$$

Due to the high hydroelectric rate in Brazil, water consumption per $\mathrm{kWh}$ generated is $410.5 \%$ higher than the USA average value and 50.22\% compared to Portugal, as shown in Figure 7.

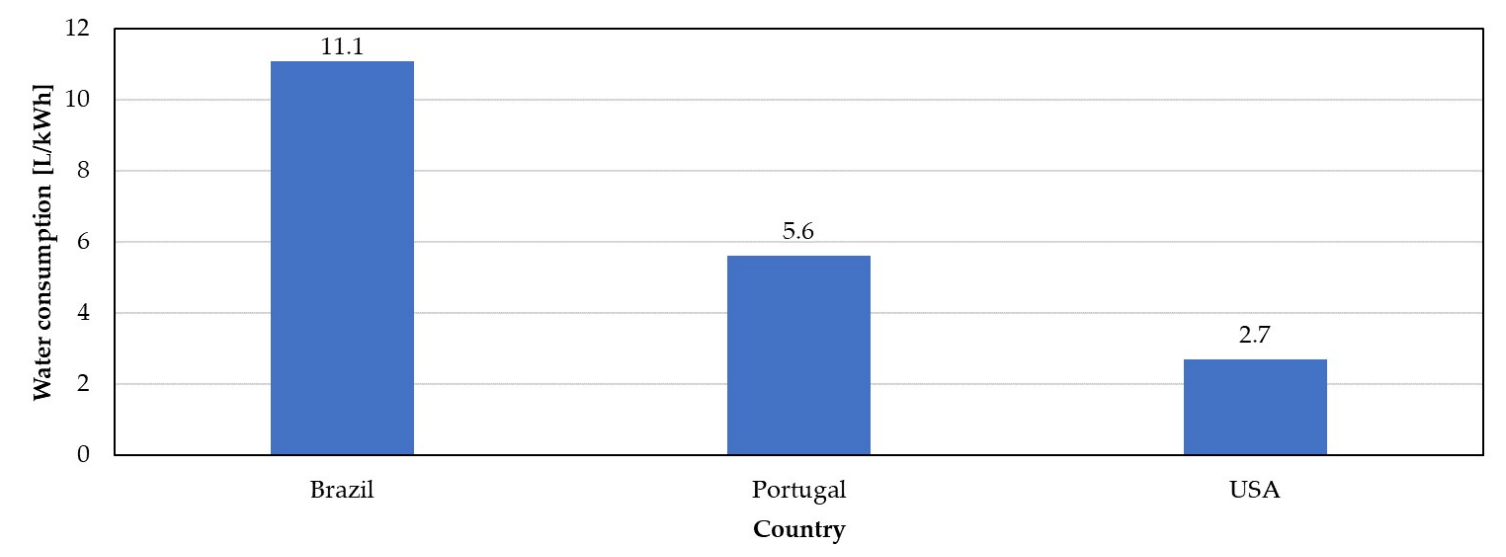

Figure 7. Water consumption (L/kWh).

With the fast development of the global economy, depletion of water resources is becoming an environmental issue of the utmost concern worldwide. The United Nations World Water Development Report published by UNESCO [12] indicates that water for current uses is becoming scarce and is leading to a water crisis. The effects that a sector can have on the environment are nowhere more visible than in the building industry. Building construction and its operations draw heavily on water from the environment. Growth in urban water use has caused a significant reduction of water tables and requires large projects that siphon supplies away from agriculture. Water used to operate buildings is a significant component of every nation's water consumption. However, this is not the only form of water consumed throughout a building's life cycle. Water is also consumed in the extraction, production, manufacturing and delivery of materials and products to site, and the actual on-site construction process, named as "embodied" water [13]. Ilha et al. [14] observed that water conservation technologies and strategies are often the most overlooked aspects of a whole-building design strategy. However, the planning for various water uses within a building is increasingly becoming a high 
priority, in part because of the increasing recognition of the water savings that can be reached through the implementation of water saving initiatives.

The LEED (Leadership in Energy and Environmental Design) already emphasizes the need for reducing water use, and states that buildings play a huge role in this effort. Buildings are the third biggest user of potable water in the USA. However, water efficiency considers only 12 of 110 points for LEED certifications (LEED v4.1). This certification has three prerequisites (outdoor water use reduction, indoor water use reduction, building level water metering) and credits for outdoor water use reduction, indoor water use reduction, cooling tower and process water use-water metering. Thus, almost $11 \%$ of LEED certification is about water efficiency. Because of the importance of water efficiency in large buildings, the use of water-cooled condenser systems may seem impractical, but the energy savings in these systems associated with less space and noise level are essential.

In simulations, as the wet bulb temperature is smaller than the dry bulb temperature, it is normal for water-cooled condensers to consume less energy than air-cooled condensers but losing water efficiency points in a LEED certification is not a desire of the certifier of green building.

Therefore, the purpose included in this paper is to create an index that can measure water directly (evaporation in water-cooled condenser) and indirectly (water needed for the production of the input energy of the system) [15].

\section{Total Water Impact (TWI)}

The Total Water Impact (TWI) index is given by the amount of the holistically required water for air conditioners over the life of the equipment (Figure 8). It was developed as a new metric for building certification.

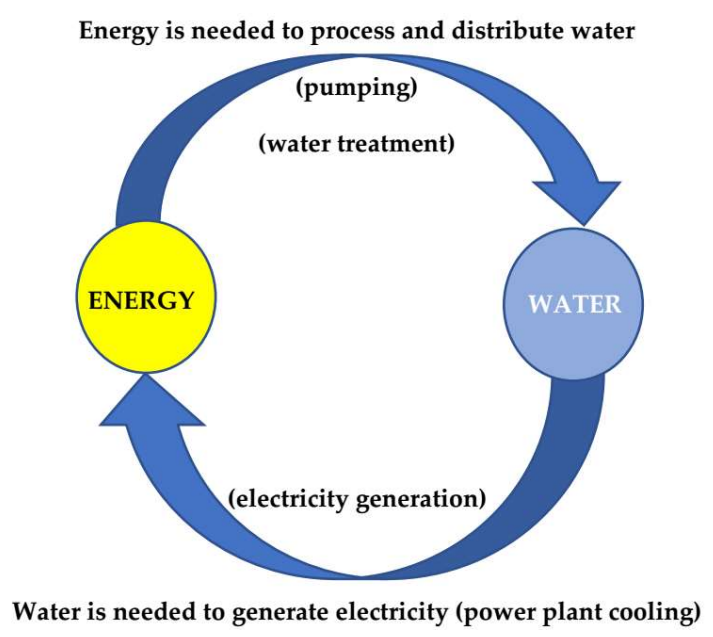

Figure 8. Energy-water nexus (adapted from Reference [11]).

The interdependencies between water and energy systems are clear and are becoming more prominent as overall development requires more resources, while their overuse and climate change impact make some resources scarcer. At the macro level, water is used at all stages of energy production and electricity generation (including renewable energy). Energy is required to extract, transport and supply water, and to treat wastewater prior to its return to the environment. At the micro level, the water-energy nexus is an important consideration for the HVAC community, dedicated to equipment design and selection and design of systems, as well as in construction operations.

One way to analyze the energy efficiency of large equipment is given by efficiency indicators, particularly, the non-standard part load value (NPLV). Specifically, NPLV is derived from the integrated part load value (IPLV). Both are used to evaluate chiller efficiency under different load conditions. The calculation formulas are the same. The only difference between IPLV and NPLV is that IPLV is 
calculated according to the condition specified in AHRI_Standard_550-590, while NPLV is calculated according to the condition of the location where the equipment is installed [16].

Thus, taking into account the above considerations, the simplified TWI is given by Equation (2):

$$
\mathrm{TWI}=(\mathrm{ATL} \cdot \mathrm{NPLV} \cdot \mathrm{ELS} \cdot \mathrm{RRW})+(\mathrm{ATL} \cdot \mathrm{ELS} \cdot \mathrm{WUTR})
$$

where TWI is Total Water Impact, in $\mathrm{m}^{3}$, ATL is Annual Thermal Load, in TON/year, NPLV is non-standard part load value, in kW/TON, ELS is equipment lifespan, in years, RRW is region-specific flow rate of water, in $\mathrm{m}^{3} / \mathrm{kW}$ generated and WUTR is water used by TON, in $\mathrm{m}^{3} / \mathrm{TON}$ of evaporation, drag and purge. Henceforth, the indicated TON unit refers to ton of refrigeration $(1 \mathrm{TON}=3.5 \mathrm{~kW})$.

The NPLV must be summed by TON from a Condensation Pump and Tower Fan. The result will be the total impact of holistic water use over the lifespan of the system.

There is already an indicator that is known as TEWI (Total Equivalent Warming Impact), which is the sum of direct and indirect emissions through refrigerant gas losses and life cycle energy consumption.

TWI is intended to measure the direct and indirect water consumption in the life cycle; therefore, the difference between TEWI and TWI is that TEWI measures GWP (Global Warming Potential), while TWI measures direct and indirect water consumption of the HVAC system in the life cycle. It is important in "Green Building" to place operational characteristics as part of the indices, as stated by Al-Ghamdi [17]. Like TEWI, TWI has advantages of using energy matrix characteristics in the calculations.

\section{Water and Air-Cooled Comparison}

In this section, the values of the air and water condensation systems' indices are determined and compared. Figure 9 shows the type of devices required when using air- or water-cooled chillers.

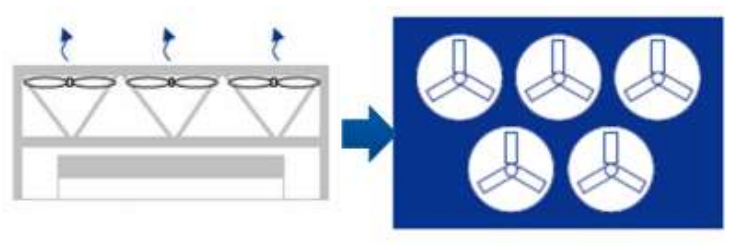

(a)

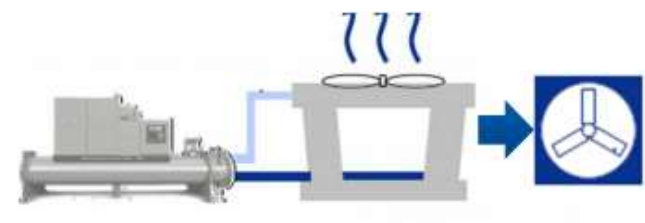

(b)

Figure 9. Comparison of (a) air- and (b) water-cooled systems [18].

The air-cooled system (Figure 9a) is a design based on dry bulb temperature:

- Larger occupied area (more surface area).

- Higher noise level.

- Higher energy consumption: lower efficiency.

- Does not consume water on site (without evaporative cooling).

The water-cooled system (Figure 9b) is a design based on wet bulb temperature:

- Smaller occupied area (usually requires equipment room).

- Low noise level.

- Lower power consumption: higher efficiency.

- Consumes water (evaporative cooling).

To compare and use in an example, air and water condensation systems for a total capacity of 200 TON with the characteristics and specifications shown in Table 1 were selected. A Brazilian air condensation chiller (Samurai screw compressor type, manufactured in Brazil) and condensation (imported) water chiller (RTHD model, manufactured in USA) were compared. Simulations were performed using the annual thermal load, the NPLV (given already with dynamic partial loads). 
The average "ASHRAE" of water consumption per TON is also an input for the simulation of the water condensation system. The simulation period considered was 1 year. Life cycle of the equipment was set for 15 years. Calculations were based on ASHRAE NPLV formulas. Specifically, the thermal load was assumed, because each enclosure has different thermal loads. The TWI for each option (air- and water-cooled), according to Equation (2), is:

$\mathrm{TWI}_{\text {air cooled }}=\left(657,000 \mathrm{TON} /\right.$ year $\times 1.06 \mathrm{~kW} / \mathrm{TON} \times 15$ years $\left.\times 0.011071 \mathrm{~m}^{3} / \mathrm{kW}\right)+(657,000 \mathrm{TON} /$ year $\times 15$ years $\left.\times 0 \mathrm{~m}^{3} / \mathrm{TON}\right)$

$\mathrm{TWI}_{\text {air cooled }}=115,650.987 \mathrm{~m}^{3}$

$\mathrm{TWI}_{\text {water cooled }}=\left(657,000 \mathrm{TON} /\right.$ year $\times 0.36 \mathrm{~kW} / \mathrm{TON} \times 15$ years $\left.\times 0.011071 \mathrm{~m}^{3} / \mathrm{kW}\right)+(657,000 \mathrm{TON} /$ year $\times 15$ years $\left.\times 0.0072 \mathrm{~m}^{3} / \mathrm{TON}\right)$

$\mathrm{TWI}_{\text {water cooled }}=110,233.694 \mathrm{~m}^{3}$

Table 1. 200 TON system parameters.

\begin{tabular}{ccc}
\hline Parameter & Air Condensation & Water Condensation \\
\hline Full Load Chiller Efficiency (kW/TON) & 1.4 & 0.65 \\
\hline NPLV partial load efficiency chiller (kW/TON) & 1.06 & 0.36 \\
\hline System total capacity (TON) & 200 & 200 \\
\hline Average annual thermal load (TON) & 150 & 150 \\
\hline Condensation Pump power (kW input) & 0 & 6.2664 \\
\hline Tower Fan power (kW input) & 0 & 4.1776 \\
\hline Hours of operation in the year (hour/year) & 4380 & 4380 \\
\hline Annual thermal load (TON/year) & 657,000 & 657,000 \\
\hline Water demand per $\mathrm{m}^{3} / \mathrm{kW}$ generated region & 0.011071 & 0.011071 \\
\hline Water Consumption Index/TON, Tower $\left(\mathrm{m}^{3} / \mathrm{TON}\right)$ & 0 & 0.0072 \\
\hline TWI $\left(\mathrm{m}^{3}\right)$ & $115,650.987$ & $110,233.694$ \\
\hline
\end{tabular}

As another example, an air and water condensation system for a total capacity of 500 TON with NPLV [17] will be compared with the characteristics shown in Table 2. The equipment of 200 and 500 TON used the same simulation with the energy consumption data of manufacturers (200 TR) or ASHRAE 90.1 (500 TR). Again, a life cycle of the equipment equal to 15 years was set. The chillers of 200 and 500 TON have different capacities and different energy efficiency, but to exchange heat of 1 TON, both have the same consumption of evaporation water. The TWI for each option (air and water condensation), according to Equation (2), is:

$\mathrm{TWI}_{\text {air cooled }}=\left(1,270,200 \mathrm{TON} /\right.$ year $\times 0.745 \mathrm{~kW} / \mathrm{TON} \times 15$ years $\left.\times 0.011071 \mathrm{~m}^{3} / \mathrm{kW}\right)+(1,270,200$ TON/year $\times 15$ years $\times 0 \mathrm{~m}^{3} / \mathrm{TON}$ )

$\mathrm{TWI}_{\text {air cooled }}=166,217.419 \mathrm{~m}^{3}$

$\mathrm{TWI}_{\text {water cooled }}=\left(1,270,200 \mathrm{TON} /\right.$ year $\times 0.38 \mathrm{~kW} / \mathrm{TON} \times 15$ years $\left.\times 0.011071 \mathrm{~m}^{3} / \mathrm{kW}\right)+(1,270,200$ TON/year $\times 15$ years $\left.\times 0.0072 \mathrm{~m}^{3} / \mathrm{TON}\right)$

$\mathrm{TWI}_{\text {water cooled }}=221,963.639 \mathrm{~m}^{3}$

In both air and water condensing systems with capacities of 200 or $500 \mathrm{TON}$, the water consumption per $\mathrm{kWh}$ generated, and the water consumption index/TON, Tower $\left(\mathrm{m}^{3} / \mathrm{TON}\right)$ have the same values.

Using the TWI calculation, which aims to understand water consumption holistically, the need for air conditioning equipment during its lifetime is determined. 
Table 2. 500 TON system parameters.

\begin{tabular}{ccc}
\hline Parameter & Air Condensation & Water Condensation \\
\hline Full Load Chiller Efficiency (kW/TON) & 1.237 & 0.585 \\
\hline NPLV partial load efficiency chiller (kW/TON) & $* 0.745$ & $* 0.38$ \\
\hline System total capacity (TON) & 500 & 500 \\
\hline Average annual thermal load (TON) & 290 & 290 \\
\hline Condensation Pump power (kW input) & 0 & 15.666 \\
\hline Tower Fan power (kW input) & 0 & 10.444 \\
\hline Hours of operation in the year (hour/year) & 4380 & 4380 \\
\hline Annual thermal load (TON/year) & $1,270,200$ & $1,270,200$ \\
\hline Water demand per $\mathrm{m}^{3} / \mathrm{kW}_{\text {generated region }}$ & 0.011071 & 0.011071 \\
\hline Water Consumption Index/TON, Tower (m $\left.{ }^{3} / \mathrm{TON}\right)$ & 0 & 0.0072 \\
\hline TWI $\left(\mathrm{m}^{3}\right.$ ) & $166,217.419$ & $221,963.639$ \\
\hline
\end{tabular}

* Efficiency based on ASHRAE 90.1-2016. Specifically, in this case IPLV = NPLV because it is not a specific city [18].

Checking the TWI results in Tables 1 and 2, specifically in the hypothetical comparison of the 200 TON air (Brazilian) and water (USA imported) systems, the TWI index was lower in the water condensation type system. That is, holistically, water consumption was lower in the water-cooled system than in the air-cooled system.

In the system with 500 TON cooling power, according to ASHRAE 90.1 of 2016 [19], considering air- and water-cooled chillers, the highest value of the TWI index was obtained in the water-cooled chiller. Larger chillers were used because normally ASHRAE 90.1 uses package air conditioning, splits, for "base line" in small buildings and not chillers.

It is understandable that designers are concerned about the efficiency of the chiller. Several factors such as poor maintenance, malfunction, improper sizing, etc., affect this efficiency. Industry stakeholders know that any element that enhances any aspect of cooler efficiency can have a huge impact. In the case of the 500 TON power system, where the 2013 ASHRAE 90.1 values were used as the NPLV source, the TWI index value was lower in the air-cooled chiller.

As new standards emerge, chiller efficiency is becoming increasingly important: water-cooled magnetic bearing chillers in warm temperatures have low NPLV, certainly leading in the future to lower TWI indexes than air-cooled chillers [18].

\section{Conclusions}

The Total Water Impact (TWI) index provides a holistic view of water consumption over a period of time. With this methodology, it can be observed that sometimes an air-cooled system has higher water consumption than a water-cooled system.

Water consumption has not yet been considered in cleaning the air condenser coil (even because the cleaning method for water condensing systems is using a brushing system). Likewise, the cleaning water for wind and solar energy sources was not included as this value has not yet been found in technical or scientific publications.

Two examples were used to demonstrate the validity of the TWI index. It was concluded that the TWI shifts from water-cooled systems to air-cooled systems as refrigeration power increases. Thus, the holistic use of water decreases for air-cooled chillers as the refrigeration power increases, while the opposite condition occurs for water-cooled chillers. That is, the holistic use of water increases with the refrigeration power required. However, it must be highlighted that the NPLV values of systems with magnetic bearing compressors in water-cooled chillers are getting smaller. The same methodology 
can be used in systems with variable refrigerant volume (VRF) with water and air condensation. In a future work, geothermal systems and dry coolers will be simulated for TWI.

Among the indicators for choosing the best cooling system and even for LEED-certified systems, the TWI can be a quality indicator. It can also be considered a pro rata TWI per TON (result divided by the cooling load in the system lifetime) for decision making. An advantage of this new index is to use the same formula in the consumption of water and energy connected by the characteristics of the region in which the systems are located. In the future, it may be part of LEED or AQUA assessment. Therefore, TWI pro rata could be an index associated to both water and energy assessments.

Author Contributions: Conceptualization, A.F.S. and P.D.G.; methodology, A.F.S.; validation, A.F.S and H.J.L.S.; formal analysis, A.F.S. and P.D.G.; investigation, A.F.S.; resources, H.J.L.S.; data curation, A.F.S. and P.D.G.; writing—original draft preparation, A.F.S., H.J.L.D.S.; writing—review and editing, P.D.G.; visualization, H.J.L.D.S.; supervision, P.D.G.; project administration, A.F.S. All authors have read and agreed to the published version of the manuscript.

Funding: This research received no external funding.

Conflicts of Interest: The authors declare no conflict of interest.

\section{Abbreviations}

ABRAVA Brazilian Association of Refrigeration, Air Conditioning, Ventilation and Heating

AHRI Air conditioning, Heating and Refrigeration Institute. Actually, does the rating of air

APREN $\quad$ Ponditioners and refrigeration units

AQUA Project to Achieve High Environmental Quality in New Projects

ASHRAE American Society of Heating, Refrigeration \& Air Conditioning Engineers

ATL Annual Thermal Load, in TON/year

ELS Equipment lifespan, in years

ghca

gnca

goca

gtca

gtgnca

GWP

HVAC

Hydroelectric generation-water consumption per kWh hydroelectric, in $\mathrm{L} / \mathrm{kWh}$

Nuclear generation-water consumption per nuclear $\mathrm{kWh}$, in $\mathrm{L} / \mathrm{kWh}$

Generation from other sources (renewable)-water consumption per kWh, in L/kWh

Coal and oil thermoelectric generation-water consumption per thermoelectric $\mathrm{kWh}$, in $\mathrm{L} / \mathrm{kWh}$

IEA

IPLV

LAG

LEED

NPLV

RRW

TEWI Total Equivalent Warming Impact Thermoelectric generation natural gas-water consumption per thermoelectric $\mathrm{kWh}$, in $\mathrm{L} / \mathrm{kWh}$ Global Warming Potential

Heating, Ventilating and Air Conditioning International Energy Agency

Integrated Part Load Value

Liters of water per $\mathrm{kWh}$ generated in the country, in $\mathrm{L} / \mathrm{kWh}$

Leadership in Energy and Environmental Design

Non-standard part load value, in $\mathrm{kW} / \mathrm{TON}$

TON Tons of Refrigeration $(1 \mathrm{TON}=3.5 \mathrm{~kW})$

TWI Total Water Impact, in $\mathrm{m}^{3}$

UNESCO United Nations Educational, Scientific and Cultural Organization

USA United States of America

WUTR Water used by TON, in $\mathrm{m}^{3} / \mathrm{TON}$ of evaporation, drag and purge

WWF Worldwide Fund for Nature

\section{References}

1. WWF. Programa Hidrológico Mundial. Available online: https://www.wwf.org.br/wwf_brasil/wwf_mundo/ (accessed on 30 March 2020). (In Portuguese).

2. MMA. Água. Ministério de Meio Ambiente (MMA). Available online: https://www.mma.gov.br/ estruturas/sedr_proecotur/_publicacao/140_publicacao09062009025910.pdf. (accessed on 30 March 2020). (In Portuguese) 
3. WINS. Water Information Network System (WINS) by the International Hydrological Programme ofUnited Nations Educational, Scientific and Cultural Organization (UNESCO). Available online: http://ihp-wins. unesco.org/ (accessed on 30 March 2020).

4. UN. World Water Development Report 2019. Available online: https://www.unwater.org/publications/worldwater-development-report-2019/ (accessed on 30 March 2020).

5. IBGE. Anuário Estatístico; Instituto Brasileiros de Geografia e Estatística-IBGE: Rio de Janeiro, Brazil, 2017. (In Portuguese)

6. ANA. Conjuntura dos Recursos Hídricos no Brasil; Agência Nacional de Águas—ANA: Brasília, Brazil, 2013. (In Portuguese)

7. IEA. Data and Statistics. Available online: https://www.iea.org/statistics/?country=WORLD\&year=2016\& category=Energy $\% 20$ supply\&indicator=TPESbySource $\&$ mode $=$ chart $\&$ dataTable=BALANCES $($ accessed on 30 March 2020).

8. ABRAVA. Seminário Brasileiro de Etiquetagem em Eficiência Energética para sistemas AVAC; ABRAVA: São Paulo, Brazil, 2018. (In Portuguese)

9. NREL. National Renewable Energy Laboratory. Available online: https://www.nrel.gov/ (accessed on 30 March 2020).

10. APREN. Boletim Energias Renováveis. Portugal; $1^{\circ}$ semestre de; APREN: Lisboa, Portugal, 2018; Available online: https://www.apren.pt/contents/publicationsreportcarditems/12-boletim-energias-renovaveis-2018. pdf (accessed on 30 March 2020). (In Portuguese)

11. EPE. Balanço Energético Nacional. Available online: http://epe.gov.br/pt/publicacoes-dados-abertos/ publicacoes/balanco-energetico-nacional-2018 (accessed on 13 September 2019). (In Portuguese)

12. UNESCO. The United Nations World Water Development Report 2019: Leaving No One Behind; UNESCO World Water Assessment Programme; United Nations Educational, Scientific and Cultural Organization (UNESCO): Paris, France, 2019.

13. Akadiri, P.O.; Chinyio, E.A.; Olomolaiye, P.O. Design of a Sustainable Building: A Conceptual Framework for Implementing Sustainability in the Building Sector. Buildings 2012, 2, 126-152. [CrossRef]

14. Ilha, M.S.O.; Oliveira, L.H.; Gonçalves, O.M. Environmental assessment of residential buildings with an emphasis on water conservation. Build. Serv. Eng. Res. Technol. 2009, 30, 15-26. [CrossRef]

15. LEED v4.1. Building Design and Construction. LEED_v4.1_BDC_Rating_System_1.2020; U.S. Green Building Council: Washington, DC, USA, 2020.

16. AHRI_Standard_550-590. Performance Rating of Water-Chilling and Heat Pump Water-Heating Packages Using the Vapor Compression Cycle; Air-Conditioning, Heating, and Refrigeration Institute (AHRI): Arlington, TX, USA, 2015.

17. Al-Ghamdi, S.G.; Bilec, M.M. Life Cycle Thinking and the LEED Rating System: Global Perspective on Building Energy Use and Environmental Impacts; Civil and Environmental Engineering, University of Pittsburgh: Pittsburgh, PA, USA, 2015.

18. ASHRAE. ASHRAE Energy Water Nexus-Denver; American Society of Heating, Refrigeration \& Air Conditioning Engineers (ASHRAE): Baltimore, MD, USA, 2016.

19. ASHRAE/ANSI/IES Standard 90.1-2016-energy Standard for Buildings except Low-Rise Residential Buildings; American Society of Heating, Refrigeration \& Air Conditioning Engineers (ASHRAE): Atlanta, GA, USA, 2016.

(C) 2020 by the authors. Licensee MDPI, Basel, Switzerland. This article is an open access article distributed under the terms and conditions of the Creative Commons Attribution (CC BY) license (http://creativecommons.org/licenses/by/4.0/). 